\title{
Gastrointestinal morphology and absorption of monosaccharides in fowls conditioned to different types and levels of dietary fibre
}

\author{
BY C. J. SAVORY \\ AFRC Institute of Animal Physiology and Genetics Research, Roslin, Midlothian EH25 9PS
}

(Received 31 August 1990-Accepted 8 May 1991)

\begin{abstract}
To test a possible influence of dietary fibre on intestinal sugar uptake, rates of absorption of $\mathbf{1 0} \mathbf{m M - D}$ $\left|\mathrm{U}-{ }^{14} \mathrm{C}\right|$ glucose and $10 \mathrm{mM}-\mathrm{D}-\left[\mathrm{U}-{ }^{14} \mathrm{C}\right]$ xylose were measured in either jejunum or (distal) caecum, by in vivo lumen perfusion, in immature female fowls preconditioned to a standard diet containing $(\mathrm{g} / \mathrm{kg})$ either $0,100,200$ or 400 added dried grass, 200 powdered cellulose, or 200 grass with a polysaccharidase enzyme supplement. When birds were killed after perfusion, dimensions of (unperfused) parts of their alimentary tracts were determined, and recoveries of ${ }^{14} \mathrm{C}$ radioactivity in some body tissues were compared with measured activities absorbed. On average, absorption of glucose was 1.9 and 1.2 times faster than xylose in jejunum and caecum respectively, although these differences varied with dietary treatment and order of perfusion. Increasing grass in the diet caused significant changes in xylose absorption rate in both jejunum and caecum, but only when it was perfused before glucose. With any one sugar and intestinal segment, mean rates of absorption were correlated positively with corresponding mean rates of fluid loss from perfusate. Although their influence on sugar absorption was not well defined, the dietary fibre treatments had more pronounced effects on gross dimensions of parts of the alimentary tract and, hence, potentially on total rates of absorption. Compared with the basal diet, addition of 100 , 200 or $400 \mathrm{~g}$ grass $/ \mathrm{kg}$ or $200 \mathrm{~g}$ cellulose $/ \mathrm{kg}$ caused significant increases in small intestine length while $200 \mathrm{~g}$ grass/kg with supplementary enzyme did not, and combined caecal length increased with the $400 \mathrm{~g}$ grass $/ \mathrm{kg}$ and the supplementary enzyme treatments. Absorbed ${ }^{14} \mathrm{C}$ activity was recovered in plasma after jejunal perfusions but not caecal ones, whereas it was recovered in liver and in the flushed perfused segment after both types of perfusion. Since there was overlap in absorption rates between jejunum and caecum, this result suggests that the liver may be able to distinguish and treat differently compounds absorbed in the two regions.
\end{abstract}

Dietary fibre: Monosaccharide uptake: Gastrointestinal morphology: Fowl

As part of an investigation into possible benefits of supplementing non-ruminant feedstuffs with exogenous polysaccharidase enzymes, rates of absorption of four constituent sugars of plant cell walls (glucose, galactose, xylose, arabinose) were compared in jejunum, ileum and caecum in the fowl (Savory \& Mitchell, 1991). Evidence was obtained that patterns of monosaccharide absorption were influenced by the composition of the diet to which birds were conditioned before being tested. Specifically, with a standard (ST) mash diet to which $200 \mathrm{~g}$ grass $/ \mathrm{kg}$ was added, the absorption rate of hexose (glucose, galactose) was $30 \%$ higher in the jejunum and $29 \%$ lower in the caecum than with the basal diet alone. This was not conclusive, however, because the diet comparison involved two groups of birds which were tested at different times. To investigate any such effects of dietary fibre in more detail, therefore, another experiment is reported here in which birds were conditioned to the same ST diet as before, diluted with either $0,100,200,400 \mathrm{~g}$ grass $/ \mathrm{kg}, 200 \mathrm{~g}$ grass $/ \mathrm{kg}$ with added enzyme, or $200 \mathrm{~g}$ cellulose $/ \mathrm{kg}$. Unlike the first experiment (Savory \& Mitchell, 1991), in which birds were each tested with all four sugars, here they were tested with one hexose (D-glucose) and one pentose (D-xylose) only, in either jejunum or caecum. 
Although effects of dietary fibre level on sugar absorption have not been studied before in the fowl, it has been shown that rates of intestinal glucose and fructose absorption were higher in chicks fed on a carbohydrate-free diet than in those fed on diets rich in carbohydrate (Gauthier et al. 1979). It has also been shown that deprivation of food for $3 \mathrm{~d}$ caused significant changes in kinetic characteristics of (electrogenic) glucose and galactose transfer in jejunum and ileum of fowls (Levin \& Mitchell, 1982). In rats, intestinal zinc transfer was influenced by manipulation of dietary fibre (Seal \& Mathers, 1989), and absorption of amino acids by manipulation of protein intake (Lis et al. 1972).

In addition to sugar transfer, dimensions of different parts of the alimentary tract were also measured in the present experiment in order to assess broader aspects of gastrointestinal (GI) adaptation to dietary fibre and to relate these to observed rates of absorption. Changes in GI morphology associated with variation in dietary fibre have been reported in wild gallinaceous birds (Leopold, 1953; Lewin, 1963; Pendergast \& Boag, 1973; Moss, 1974) and captive ones (Moss, 1972; Savory \& Gentle, 1976a, b), but not, so far, in the fowl. Finally, since the method used here for measuring rates of intestinal absorption (Levin et al. 1983) is based on in vivo lumen perfusion of ${ }^{14} \mathrm{C}$-labelled compounds, an attempt was made to validate the technique by relating levels of ${ }^{14} \mathrm{C}$ radioactivity absorbed during perfusion to those recovered in plasma and liver at the end of the test.

\section{MATERIALS AND METHODS}

Subjects and diets

The subjects were ninety-six immature female medium-hybrid (Rhode Island Red $\times$ Light Sussex) fowls, 12-14 weeks old and weighing 1.03-1.50 kg. Separate hatches were used to ensure that birds were all about the same age when tested (Table 3), the whole experiment taking about 3 months to complete. Within each hatch, equal numbers of birds were conditioned to each of the six diets in Table 1 for at least 3 weeks before testing, which was the time taken for complete adaptation of GI morphology after manipulation of dietary fibre content in Japanese quail (Coturnix coturnix japonica; Savory \& Gentle, 1976b). All birds were kept on a $14 \mathrm{~h}$ photoperiod at about $20^{\circ}$ and had $a d$ lib. access to food and water until the time of testing.

\section{Experimental design}

With each dietary treatment, half the sixteen birds were tested in the jejunum and half in the (left) caecum. With each intestinal segment, half the eight birds were tested with glucose and then xylose, and half in the reverse order. There were, thus, six diets $\times$ two segments $\times$ two orders $\times$ four birds, and within each hatch different treatments were tested in random order.

\section{Perfusion procedure for measuring rates of absorption}

Solutions of $10 \mathrm{~mm}$-D-glucose and D-xylose were prepared in bicarbonate-saline $(9 \mathrm{~g}$ sodium chloride/1) buffer (Krebs \& Henseleit, 1932), with each containing enough of the respective sugar in [U-14]-labelled form (Amersham International) to give a specific activity of $0.4 \mu \mathrm{Ci}$ per $50 \mathrm{ml}$, and $100 \mathrm{mg}$ fluorescein isothiocyanate (FITC) dextran (Sigma) per $250 \mathrm{ml}$ for measuring fluid loss during perfusion. Reasons for choosing the $10 \mathrm{~mm}$ concentration and FITC dextran marker were given previously (Savory \& Mitchell, 1991). Up to three birds were tested per day according to the perfusion schedule in Table 2. Methods for inducing and maintaining anaesthesia, exposing and cannulating segments of jejunum and caecum, maintaining birds' body heat and the $\mathrm{pH}$ of perfusates, measuring fluid loss and ${ }^{14} \mathrm{C}$ radioactivity, and calculating rates of absorption of the glucose and xylose were all as described previously (Savory \& Mitchell, 1991). 
Table 1. Composition of test diets $(\mathrm{g} / \mathrm{kg})$

\begin{tabular}{|c|c|c|c|c|c|c|}
\hline Diet... & $(\mathrm{ST})$ & $\begin{array}{c}(\mathrm{ST}+100 \mathrm{~g} \\
\text { grass } / \mathrm{kg})\end{array}$ & $\begin{array}{c}(\mathrm{ST}+200 \mathrm{~g} \\
\text { grass } / \mathrm{kg})\end{array}$ & $\begin{array}{c}40 \mathrm{G} \\
(\mathrm{ST}+ \\
400 \mathrm{~g} \\
\text { grass } / \mathrm{kg})\end{array}$ & $\begin{array}{c}20 \mathrm{C} \\
(\mathrm{ST}+200 \mathrm{~g} \\
\text { cellulose } / \mathrm{kg})\end{array}$ & $\begin{array}{c}20 \mathrm{G} / \mathrm{E} \\
(\mathrm{ST}+200 \mathrm{~g} \\
\text { grass } / \mathrm{kg} \\
+10 \mathrm{~g} \\
\mathrm{FENZ} / \mathrm{kg})\end{array}$ \\
\hline Barley & 300 & 270 & 240 & 180 & 240 & 237.6 \\
\hline Maize & 200 & 180 & 160 & 120 & 160 & 158.4 \\
\hline Wheat & 280 & 252 & 224 & 168 & 224 & $221 \cdot 8$ \\
\hline Grass & 50 & 145 & 240 & 430 & 40 & $237 \cdot 6$ \\
\hline Soya bean & 100 & 90 & 80 & 60 & 80 & $79 \cdot 2$ \\
\hline Herring & 35 & $31 \cdot 5$ & 28 & 21 & 28 & 27.7 \\
\hline Limestone & 10 & 9 & 8 & 6 & 8 & 7.9 \\
\hline Dicalcium phosphate & $17 \cdot 5$ & $15 \cdot 8$ & 14 & $10 \cdot 5$ & 14 & 13.9 \\
\hline Cellulose (CEPO) & - & - & - & - & 200 & - \\
\hline Salt & $2 \cdot 5$ & $2 \cdot 3$ & 2 & $1 \cdot 5$ & 2 & $2 \cdot 0$ \\
\hline Vitamin mix & $2 \cdot 5$ & $2 \cdot 3$ & 2 & $1 \cdot 5$ & 2 & 20 \\
\hline Mineral mix & $2 \cdot 5$ & $2 \cdot 3$ & 2 & $1 \cdot 5$ & 2 & $2 \cdot 0$ \\
\hline Enzyme (FENZ)* & - & - & 一 & - & - & $10 \cdot 0$ \\
\hline $\mathrm{NDF}+$ & 52 & $89 \ddagger$ & 125 & $198 t$ & $>125_{t}^{+}$ & $124 \div$ \\
\hline $\begin{array}{l}\text { Crude protein } \\
(\text { nitrogen } \times 6.25) \dagger\end{array}$ & 148 & $154 \ddagger$ & 160 & $172 \ddagger$ & $123 \ddagger$ & 1617 \\
\hline $\operatorname{AME} \nmid(\mathrm{MJ} / \mathrm{kg})$ & $11 \cdot 2$ & $10-84$ & $10 \cdot 4$ & $9 \cdot 6_{+}^{+}$ & $9 \cdot 3 \ddagger$ & $10 \cdot 3 t$ \\
\hline
\end{tabular}

NDF, neutral-detergent fibre; AME, apparent metabolizable energy; ST, basal diet.

* A composite enzyme preparation containing different polysaccharidase activities, details of which are confidential.

$\dagger$ NDF, crude protein and AME were measured with the $0 \mathrm{G}$ and $20 \mathrm{G}$ diets (Savory \& Mitchell, 1991).

$\ddagger$ These values were extrapolated from those measured with the $0 \mathrm{G}$ and $20 \mathrm{G}$ diets.

\section{Table 2. Perfusion schedule}

1. Anaesthetize bird with halothane (Fluothane; ICI; $30 \mathrm{ml} / 1,21 / \mathrm{min}$ )

2. Expose intestinal segment, clean thoroughly with saline $(9 \mathrm{~g}$ sodium chloride/1), implant cannulas and reposition segment in abdomen

3. Fill system from $50 \mathrm{ml} \mathrm{Krebs} \mathrm{Ringer} \mathrm{(buffer)} \mathrm{solution} \mathrm{(flow-rate} 14.5 \mathrm{ml} / \mathrm{min}$, about $2 \mathrm{~min}$ )

4. Perfuse with Krebs Ringer (buffer) solution for $5 \mathrm{~min}$ (flow-rate $4 \mathrm{ml} / \mathrm{min}$ )

5. Empty system (flow-rate $14.5 \mathrm{ml} / \mathrm{min}$, about $2 \mathrm{~min}$ )

6. Fill system from $50 \mathrm{ml}$ sugar 1

7. Perfusion with sugar 1 for $2 \mathrm{~min}$ (flow-rate $4 \mathrm{ml} / \mathrm{min}$ )

8. Empty system and remove two $1 \mathrm{ml}$ portions

9. Fill system from $50 \mathrm{ml}$ sugar 1

10. Perfuse with sugar I for $15 \mathrm{~min}$ (flow-rate $4 \mathrm{ml} / \mathrm{min}$ ). Measure breathing rate and body temperature (with rectal probe)

11. Empty system and remove two $1 \mathrm{ml}$ portions

12. Return to step 3 and repeat (steps 3-11) for sugar 2 (total time $65-70 \mathrm{~min}$ for complete schedule)

At the end of testing, remove $1 \mathrm{ml}$ blood from wing vein into a heparinized syringe. Fill system with Krebs and flush segment (flow-rate $4 \mathrm{ml} / \mathrm{min}$ ) for 5-10 min. Empty system, kill bird with $2 \mathrm{ml}$ sodium pentobarbitone (Sagital, May and Baker) injected into wing vein. Remove perfused segment and measure immediately to the nearest $0.1 \mathrm{~cm}$ (in a vertical position with a $10 \mathrm{~g}$ weight attached to bottom end). Measure 'wet ' weight before and after removing $0.25 \mathrm{~g}$ portion for radioactivity (disintegrations $/ \mathrm{min}$ ) count, and dry weight of remainder after oven-drying at $80^{\circ}$ for $48 \mathrm{~h}$. Remove about $4 \mathrm{~g}$ liver for radioactivity count, prepare portion of intestine for villi measurement, measure gut dimensions. 


\section{Recovery of absorbed ${ }^{14} \mathrm{C}$ activity}

In order to determine whether measured absorption of $\mathrm{U}-{ }^{14} \mathrm{C}$-labelled sugars in jejunum and caecum was reflected by ${ }^{14} \mathrm{C}$ activity in circulating plasma, $1 \mathrm{ml}$ blood was removed by wing vein from each bird at the end of testing (Table 2). This was centrifuged $(2500 \mathrm{~g}$, $5 \mathrm{~min}$ ), $0.5 \mathrm{ml}$ plasma was added to $4.5 \mathrm{ml}$ Optiphase $\mathrm{X}$ (Pharmacia Ltd) and its radioactivity measured in a liquid-scintillation counter (LKB Wallac Rackbeta). The results of these measurements were anomalous, so radioactivity in the liver was also measured after removing a portion from the freshly killed bird. Later it was considered that some absorbed ${ }^{14} \mathrm{C}$ activity might be retained in enterocytes on the villi in perfused segments so, after thorough flushing with Krebs' bicarbonate buffer, a small portion of the (fresh) segment was also removed. Liver and intestinal portions were kept deep-frozen until the end of the experiment, when they were all analysed at the same time. A weighed amount $(0.15-0.25 \mathrm{~g}$ wet weight) of each was dissolved completely in $2.0 \mathrm{ml}$ Optisolve (Pharmacia Ltd; in about $3 \mathrm{~d}$ ), and then two $0.5 \mathrm{ml}$ portions of this were each added to $4.5 \mathrm{ml}$ Optiscint $\mathrm{T}$ (Pharmacia Ltd) to measure radioactivity. Since the collections of liver and (especially) intestinal segments commenced after the start of the experiment, their total sample sizes are less than ninety-six (Table 9).

\section{GI morphology measurements}

After birds were killed at the end of testing, measurements were made of lengths and weights of perfused intestinal segments in all birds (Table 2), of combined caeca length in birds with perfused jejunum, and of empty gizzard weight and lengths of duodenum, jejunum, ileum and colo-rectum in birds with perfused caecum. With jejunum perfusions, a segment $(1 \mathrm{~cm})$ of jejunum was removed immediately anterior to the perfused section, and with caecal perfusions, a segment $(1 \mathrm{~cm})$ was removed from the unperfused (right) caecum, $2 \mathrm{~cm}$ from its distal end. These segments were opened out, cleaned with isotonic saline, pinned on bits of balsa wood with mucosa uppermost, and then inverted in buffered neutral formalin for 1 week to be fixed. They were then sectioned and stained with haematoxylin and eosin, and lengths of complete villi (ten with caecum but usually fewer with jejunum) were measured to the nearest $0.05 \mathrm{~mm}$ with a binocular microscope and graticule scale, to obtain mean villus length for each segment.

\section{Food intake and digestibility measurements}

Mean daily food intakes were obtained from six birds on each dietary treatment by measuring weights of food eaten over periods of 4-10 d, when they were housed individually and had been fed on their respective diets for at least 2 weeks. To measure digestibilities, four (conditioned) birds on each treatment were fed their respective diet supplemented with $4 \mathrm{~g}$ titanium dioxide/ $\mathrm{kg}$ for $3 \mathrm{~d}$, their droppings trays were cleaned at the start of the third day, and all excreta produced by each bird on the third day were collected. Excreta and a sample of each marked food were oven-dried and analysed for $\mathrm{TiO}_{2}$, and apparent digestibility of the food was calculated for each bird (Peddie et al. 1982).

\section{Statistical analysis}

Age and body-weight at testing, daily food intake, apparent digestibility and GI morphology measurements were each compared between dietary treatments by one-way ANOVA (Tables 3,4). Significance of effects of diet, intestinal segment, order of perfusion and interactions on absorption variables was obtained from three-way ANOVA; and in addition, the effect of 'grass linear dose' (diets 0G, 10G, 20G, 40G) was tested by regression analysis (Table 5). Levels of ${ }^{14} \mathrm{C}$ radioactivity that were absorbed during perfusion and 
Table 3. Mean age and body-weight at testing, daily intake and apparent digestihility of test diets, for birds conditioned to the diets for at least 3 weeks

\begin{tabular}{|c|c|c|c|c|c|c|}
\hline $\operatorname{Diet}^{*} \ldots$ & $n$ & $0 \mathrm{G}$ & $10 \mathrm{G}$ & $20 \mathrm{G}$ & SED & $\begin{array}{c}\text { Statistical } \\
\text { significance of } \\
\text { variance ratio }\end{array}$ \\
\hline Age (d) & I6 & 90.8 & $92 \cdot 1$ & $92 \cdot 0$ & 1.9 & NS \\
\hline Body-wt $(\mathrm{kg})$ & 16 & $1 \cdot 26$ & $1 \cdot 27$ & $1 \cdot 26$ & $0 \cdot 04$ & NS \\
\hline Daily intake $(\mathrm{g})$ & 6 & $92 \cdot 5^{\mathrm{a}}$ & $94 \cdot 0^{\mathrm{a}}$ & $96.8^{a}$ & $3 \cdot 8$ & $P=0.042$ \\
\hline Digestibility $(\%)$ & 4 & $70 \cdot 2^{\mathrm{a}}$ & $66 \cdot 4^{b}$ & $58.8^{\prime \prime}$ & $1 \cdot 4$ & $P<0.001$ \\
\hline Diet*... & $n$ & $40 \mathrm{G}$ & $20 \mathrm{C}$ & $20 \mathrm{G} / \mathrm{E}$ & SED & $\begin{array}{c}\text { Statistical } \\
\text { significance of } \\
\text { variance ratio }\end{array}$ \\
\hline Age (d) & 16 & $92 \cdot 0$ & $92 \cdot 1$ & $92 \cdot 3$ & 1.9 & NS \\
\hline Body-wt $(\mathrm{kg})$ & 16 & $1 \cdot 22$ & $1 \cdot 22$ & $1 \cdot 32$ & 0.04 & NS \\
\hline Daily intake (g) & 6 & $97 \cdot 0^{\mathrm{a}}$ & $104 \cdot 8^{\mathrm{h}}$ & $95 \cdot 7^{\mathrm{a}}$ & $3 \cdot 8$ & $P=0.042$ \\
\hline Digestibility $(\%)$ & 4 & $56 \cdot 5^{c}$ & $58 \cdot 3^{\prime}$ & $63 \cdot 0^{4}$ & $1 \cdot 4$ & $P<0.001$ \\
\hline
\end{tabular}

$0 \mathrm{G}$, basal diet; 10G, 20G, 40G, basal diet with 100,200 and $400 \mathrm{~g}$ grass $/ \mathrm{kg} ; 20 \mathrm{C}$, basal diet with $200 \mathrm{~g}$ cellulose $/ \mathrm{kg}: 20 \mathrm{G} / \mathrm{E}$, basal diet with $200 \mathrm{~g}$ grass $/ \mathrm{kg}$ and $10 \mathrm{~g}$ enzyme preparation $/ \mathrm{kg}$.

$n$, sample size with each diet; SED, standard error of the difference between means; NS, not significant $(P>$ $0 \cdot 05)$

a. b. A. a Means with the same superscript letter were not significantly different

* For details of diets, see Table 1 .

recovered in plasma, liver and intestinal segment were compared between jejunum- and caecum-perfused birds by $t$ test (Table 9), and also correlated with each other within the two groups of birds (Table 10).

\section{RESULTS}

Food intake and digestibility

Body-weight at the time of testing was greatest with the enzyme-supplemented diet $(20 \mathrm{G} / \mathrm{E})$, but did not differ significantly $(P>0.05)$ between dietary treatments (Table 3$)$. Daily food intake was significantly higher with diet $20 \mathrm{C}$ than with the other diets. Addition of grass or cellulose caused reductions in apparent digestibility compared with the basal diet $(0 \mathrm{G})$, but the enzyme supplement (diet $20 \mathrm{G} / \mathrm{E}$ ) caused a significant $7 \%$ improvement in digestibility compared with the unsupplemented diet $20 \mathrm{G}$ (Table 3).

\section{GI morphology}

Empty gizzard weight, jejunum length, and jejunal and caecal villus lengths did not differ significantly between treatments (Table 4). Lengths of duodenum, ileum and total small intestine, however, all increased with addition of grass or cellulose, except when enzyme was added as well (diet $20 \mathrm{G} / \mathrm{E}$ ). Combined caeca were longer with diets $40 \mathrm{G}$ and $20 \mathrm{G} / \mathrm{E}$ than with other treatments, while the colo-rectum was shortest with the basal diet $(0 \mathrm{G})$.

\section{Rates of sugar absorption}

Perfused segments of intestine did not differ significantly between dietary treatments in either length (overall means: jejunum $12.9 \mathrm{~cm}$, caecum $8.3 \mathrm{~cm}$ ) or dry weight (jejunum $0.88 \mathrm{~g}$, caecum $0.35 \mathrm{~g}$ ).

On average, glucose absorption was 1.9 and 1.2 times faster than xylose absorption in jejunum and caecum respectively, although these differences varied with dietary treatment 


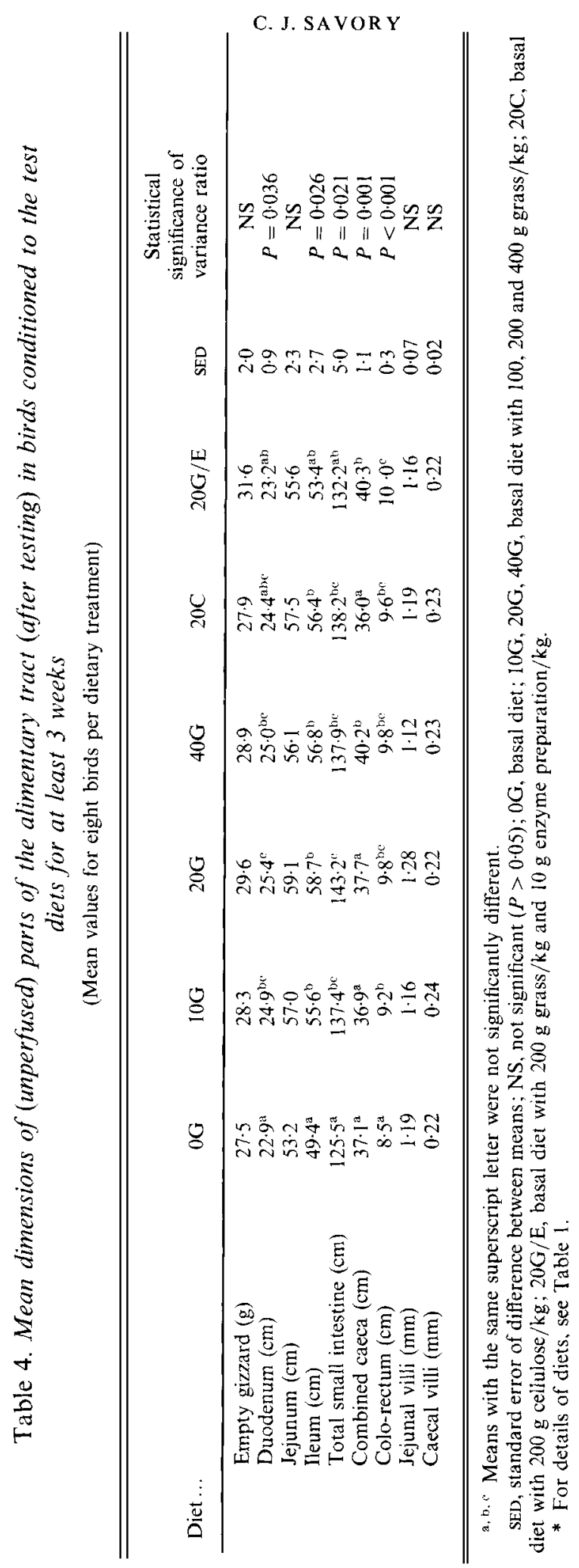


Table 5. Significance of effects of diet (six diets), intestinal segment (jejunum, caecum) and order of perfusion (glucose-xylose, xylose-glucose) on absorption variables, from three-way ANOVA (variance ratios with 72 residual and 95 total df)

\begin{tabular}{|c|c|c|c|c|c|c|}
\hline \multirow[b]{2}{*}{ Effect } & \multicolumn{4}{|c|}{ Absorption } & \multicolumn{2}{|c|}{ Fluid loss } \\
\hline & $\begin{array}{c}\text { Glucose } \\
(/ \mathrm{cm})\end{array}$ & $\begin{array}{c}\text { Xylose } \\
(/ \mathrm{cm})\end{array}$ & $\begin{array}{c}\text { Glucose } \\
(/ \mathrm{g})\end{array}$ & $\begin{array}{c}\text { Xylose } \\
(/ g)\end{array}$ & $\begin{array}{c}\text { Glucose } \\
(/ \mathrm{cm})\end{array}$ & $\begin{array}{c}\text { Xylose } \\
(/ \mathrm{cm})\end{array}$ \\
\hline Diet & - & - & -- & - & -- & $* *$ \\
\hline (Grass linear dose) & - & - & - & - & - & $* *$ \\
\hline Segment & - & * & $* * *$ & $* * *$ & ** & $* *$ \\
\hline Order & $* * *$ & * & $* * *$ & $*$ & -- & - \\
\hline Diet/segment & - & - & - & - & -- & $* *$ \\
\hline (Dose/segment) & - & $* * *$ & - & ** & - & $* * *$ \\
\hline Diet/order & - & - & - & - & - & - \\
\hline (Dose/order) & $*$ & * & - & $*$ & ** & $* * *$ \\
\hline Segment & - & ** & * & ** & -- & $* *$ \\
\hline Diet/segment/order & - & - & - & - & - & $*$ \\
\hline (Dose/segment/order) & - & ** & - & * & - & $* * *$ \\
\hline
\end{tabular}

Dose, grass linear dose, regression $v$. diets $0 \mathrm{G}, 10 \mathrm{G}, 20 \mathrm{G}, 40 \mathrm{G}$.

${ }^{*} P<0.05,{ }^{* *} P<0.01,{ }^{* * *} P<0.001$, all other variance ratios not significant $(P>0.05)$.

and order of perfusion (Tables 6,7). On a unit length basis, glucose absorption was affected significantly by order of perfusion and by a dietary grass (linear) dose $x$ order interaction (Table 5). Thus, in both jejunum and caecum, glucose absorption was faster when it was perfused first, and this difference between first and second perfusions tended to decline with increasing grass in the diet (Table 6). With xylose absorption there were six significant effects, four of which were interactions (Table 5). Thus, there were overall tendencies for xylose absorption to be faster when perfused first, and faster in the caecum than jejunum. However, these effects were due mainly to very high rates of absorption when xylose was perfused first in the caecum with diets $0 \mathrm{G}$ and $10 \mathrm{G}$, and there was no consistent effect of order of perfusion in the jejunum (Table 6). Also, with increasing grass in the diet, xylose absorption rates during the first perfusion increased in jejunum but decreased in caecum.

Because perfused segments weighed less per unit length with caecum (overall mean $42 \mathrm{mg} / \mathrm{cm}$ ) than jejunum $(69 \mathrm{mg} / \mathrm{cm})$, reflecting longer villi (Table 4) and thicker muscle layers (Gentle \& Savory, 1975) with the latter, absorption rates in the caecum were proportionately greater per unit weight than per unit length. Thus, on a dry-weight basis, absorption rates of both glucose and xylose were significantly higher in the caecum than jejunum (Tables 5 and 7). With glucose, the effect of order of perfusion, which was greater in the caecum than jejunum, was significant as before, but the effect of the grass dose $\times$ order interaction was not. With xylose, significant effects were the same as on a length basis, with the greatest influence coming from the very high values when it was perfused first in the caecum with diets $0 \mathrm{G}$ and $10 \mathrm{G}$.

\section{Rates of fluid transfer}

Overall mean rates of fluid loss from perfusate across intestinal epithelium did not differ between glucose and xylose perfusions in either jejunum or caecum (Table 8 ). With both sugars, however, fluid loss was greater in the caecum than in the jejunum (Tables 5 and 8 ), reflecting the fact that the hind-gut is the main site of water resorption (Thomas \& Skadhauge, 1988). When glucose was perfused first, the associated fluid loss in both jejunum and caecum tended to decline with increasing grass in the diet. This was also true 
Table 6. Mean rates of absorption of glucose and xylose (10 $\mathrm{mm}$ solutions) in the jejunum and caecum of birds conditioned to six test diets (nmol/min per $\mathrm{cm}$ )

\begin{tabular}{|c|c|c|c|c|c|c|c|c|}
\hline \multirow{3}{*}{$\begin{array}{l}\text { Sugar ... } \\
\text { Segment ... } \\
\text { Order* ... }\end{array}$} & \multicolumn{4}{|c|}{ Giucose (SED 73) } & \multicolumn{4}{|c|}{ Xylose (SED 64) } \\
\hline & \multicolumn{2}{|c|}{ Jejunum } & \multicolumn{2}{|c|}{ Caecum } & \multicolumn{2}{|c|}{ Jejunum } & \multicolumn{2}{|c|}{ Caecum } \\
\hline & 1 & 2 & 1 & 2 & 1 & 2 & 1 & 2 \\
\hline \multicolumn{9}{|l|}{ Diet } \\
\hline $0 \mathrm{G}$ & 333 & 183 & 318 & 164 & 91 & 159 & 450 & 95 \\
\hline $10 \mathrm{G}$ & 302 & 175 & 373 & 164 & 128 & 89 & 269 & 137 \\
\hline $20 \mathrm{G}$ & 280 & 202 & 237 & 129 & 164 & 197 & 187 & 134 \\
\hline $40 \mathrm{G}$ & 284 & 308 & 277 & 202 & 164 & 188 & 121 & 120 \\
\hline $20 \mathrm{C}$ & 238 & 230 & 266 & 216 & 157 & 156 & 206 & 195 \\
\hline $20 \mathrm{G} / \mathrm{E}$ & 373 & 290 & 195 & 218 & 81 & 135 & 164 & 133 \\
\hline Mean ( $n$ 24) & 302 & 231 & 278 & 182 & 131 & 154 & 233 & 136 \\
\hline
\end{tabular}

SED, standard error of the difference between means $(n 4) ; 0 \mathrm{G}$, basal diet; $10 \mathrm{G}, 20 \mathrm{G}, 40 \mathrm{G}$, basal diet with 100 , 200 and $400 \mathrm{~g}$ grass $/ \mathrm{kg} ; 20 \mathrm{C}$, basal diet with $200 \mathrm{~g}$ cellulose $/ \mathrm{kg} ; 20 \mathrm{G} / \mathrm{E}$, basal diet with $200 \mathrm{~g}$ grass $/ \mathrm{kg}$ and $10 \mathrm{~g}$ enzyme preparation $/ \mathrm{kg}$.

* The sugar concerned was perfused first or second.

when xylose was perfused first, but in the caecum only, where the effect was very marked. With xylose perfusions, fluid loss in the caecum was greater $(P<0.05)$ with diet $20 \mathrm{C}$ than diet 20G. With any one sugar and segment, mean fluid loss values in Table 8 were correlated positively with corresponding mean absorption rates in Tables 6 and $7(P<0.01$ or $0.001, n$ 12).

\section{Recovery of absorbed ${ }^{14} \mathrm{C}$ activity}

There were no significant effects of dietary treatment or order of perfusion on recovery of ${ }^{14} \mathrm{C}$ activity in plasma, ljver or perfused intestinal segment, so values from all treatments were combined for comparing jejunum and caecum.

Total radioactivity absorbed, and that absorbed with the second sugar only, were greater with jejunum than caecum perfusions (Table 9), mainly because of the difference in length of perfused segment (see overall means, p. 81). Radioactivity (disintegrations/min; dpm) in plasma after jejunum perfusions ranged from 58 to 171, but those after caecum perfusions were nearly all about background (radiation) level $(12 \mathrm{dpm})$, with the highest being $32 \mathrm{dpm}$. Thus, absorbed ${ }^{14} \mathrm{C}$ activity was recovered in plasma after perfusions in the jejunum but not in the caecum. Activity recovered in the liver, however, did not differ significantly between jejunum and caecum perfusions (although the mean was $11 \%$ higher with the caecum, Table 9), thus validating measured sugar absorption from the caecum. Although activity recovered per gram of perfused segment did not differ significantly between jejunum and caecum, this was because of one exceptionally high radioactivity value (11290 dpm) with the jejunum, which caused its larger standard error (Table 9). If this value is ignored, then mean activity recovered in jejunum was higher $(P<0.05)$, presumably reflecting greater surface area on its longer villi (Table 4) for potential $U_{-}{ }^{14} \mathrm{C}$ labelled sugar retention.

${ }^{14} \mathrm{C}$ activity in plasma reflected total activity absorbed, and that absorbed with the second sugar only, with jejunum but not caecum perfusions (Table 10 ). Instead, ${ }^{14} \mathrm{C}$ activity absorbed in the caecum was correlated negatively with that recovered in liver, and recovery in perfused caecum was also correlated negatively with that in liver. Multiple regression analyses confirmed that these were the only significant relationships. 
GI RESPONSES TO DIETARY FIBRE IN THE FOWL

Table 7. Mean rates of absorption of glucose and xylose (10 mM solutions) in the jejunum and caecum of birds conditioned to six test diets (nmol/min per $g$ dry $w t$ )

\begin{tabular}{|c|c|c|c|c|c|c|c|c|}
\hline \multirow{3}{*}{$\begin{array}{l}\text { Sugar ... } \\
\text { Segment... } \\
\text { Order*... }\end{array}$} & \multicolumn{4}{|c|}{ Glucose (SED 1494) } & \multicolumn{4}{|c|}{ Xylose (SED 1496) } \\
\hline & \multicolumn{2}{|c|}{ Jejunum } & \multicolumn{2}{|c|}{ Caecum } & \multicolumn{2}{|c|}{ Jejunum } & \multicolumn{2}{|c|}{ Caecum } \\
\hline & 1 & 2 & 1 & 2 & 1 & 2 & 1 & 2 \\
\hline \multicolumn{9}{|l|}{ Diet } \\
\hline $0 \mathrm{G}$ & 4195 & 2847 & 7249 & 3705 & 1390 & 2068 & 10167 & 2454 \\
\hline $10 \mathrm{G}$ & 4161 & 2440 & 8927 & 3654 & 1773 & 1206 & 6114 & 3358 \\
\hline $20 \mathrm{G}$ & 4216 & 2895 & 5384 & 3316 & 2180 & 2961 & 4684 & 3008 \\
\hline $40 G$ & 4347 & 4520 & 8093 & 5462 & 2455 & 2780 & 3132 & 3550 \\
\hline $20 \mathrm{C}$ & 3683 & 3973 & 6243 & 4875 & 2609 & 2329 & 4989 & 4544 \\
\hline $20 \mathrm{G} / \mathrm{E}$ & 5465 & 4659 & 4820 & 4770 & 1325 & 1957 & 3951 & 3270 \\
\hline $\operatorname{Mean}(n 24)$ & 4345 & 3556 & 6786 & 4297 & 1955 & 2217 & 5506 & 3364 \\
\hline
\end{tabular}

SED, standard error of the difference between means $(n 4) ; 0 \mathrm{G}$, basal diet; $10 \mathrm{G}, 20 \mathrm{G}, 40 \mathrm{G}$, basal diet with 100 , 200 and $400 \mathrm{~g}$ grass $/ \mathrm{kg} ; 20 \mathrm{C}$, basal diet with $200 \mathrm{~g}$ cellulose $/ \mathrm{kg} ; 20 \mathrm{G} / \mathrm{E}$, basal diet with $200 \mathrm{~g}$ grass $/ \mathrm{kg}$ and $10 \mathrm{~g}$ enzyme preparation $/ \mathrm{kg}$.

* The sugar concerned was perfused first or second.

Table 8. Mean rates of fluid loss from $10 \mathrm{~mm}$ solutions of glucose and xylose in the jejunum and caecum of birds conditioned to six test diets $(\mu l / \mathrm{min}$ per $\mathrm{cm})$

\begin{tabular}{|c|c|c|c|c|c|c|c|c|}
\hline \multirow{3}{*}{$\begin{array}{l}\text { Sugar ... } \\
\text { Segment ... } \\
\text { Order* ... }\end{array}$} & \multicolumn{4}{|c|}{ Glucose (SED 6-6) } & \multicolumn{4}{|c|}{ Xylose (SED $5 \cdot 1$ ) } \\
\hline & \multicolumn{2}{|c|}{ Jejunum } & \multicolumn{2}{|c|}{ Caecum } & \multicolumn{2}{|c|}{ Jejunum } & \multicolumn{2}{|c|}{ Caecum } \\
\hline & 1 & 2 & 1 & 2 & 1 & 2 & 1 & 2 \\
\hline \multicolumn{9}{|l|}{ Diet } \\
\hline $0 \mathrm{G}$ & 11.7 & $7 \cdot 8$ & $21 \cdot 7$ & $11 \cdot 8$ & 6.7 & $11 \cdot 0$ & $42 \cdot 1$ & $9 \cdot 2$ \\
\hline $10 \mathrm{G}$ & 10.5 & $9 \cdot 3$ & $34 \cdot 4$ & $12 \cdot 5$ & $12 \cdot 8$ & 6.9 & $16 \cdot 3$ & $15 \cdot 0$ \\
\hline $20 \mathrm{G}$ & $8 \cdot 3$ & $7 \cdot 9$ & 16.7 & 8.5 & 13.6 & $13 \cdot 0$ & 13.4 & $9 \cdot 3$ \\
\hline $40 G$ & $8 \cdot 9$ & 16.9 & $11 \cdot 0$ & 19.5 & $\begin{array}{r}150 \\
9 \cdot 8\end{array}$ & $11 \cdot 5$ & $4 \cdot 7$ & $14 \cdot 0$ \\
\hline $20 \mathrm{C}$ & $6 \cdot 4$ & $8 \cdot 0$ & $25 \cdot 1$ & $7 \cdot 0$ & 13.7 & $12 \cdot 4$ & $20 \cdot 0$ & $21 \cdot 1$ \\
\hline $20 \mathrm{G} / \mathrm{E}$ & $14 \cdot 6$ & $13 \cdot 1$ & 9.9 & $18 \cdot 1$ & $5 \cdot 0$ & $14 \cdot 4$ & $14 \cdot 2$ & $3 \cdot 2$ \\
\hline Mean ( $n$ 24) & 10.1 & $10 \cdot 5$ & $19 \cdot 8$ & $12 \cdot 9$ & $10 \cdot 3$ & $11-5$ & 18.5 & $12 \cdot 0$ \\
\hline
\end{tabular}

SED, standard error of the difference between means $(n 4)$; $0 \mathrm{G}$, basal diet; $10 \mathrm{G}, 20 \mathrm{G}, 40 \mathrm{G}$, basal diet with 100 , 200 and $400 \mathrm{~g}$ grass $/ \mathrm{kg} ; 20 \mathrm{C}$, basal diet with $200 \mathrm{~g}$ cellulose $/ \mathrm{kg} ; 20 \mathrm{G} / \mathrm{E}$, basal diet with $200 \mathrm{~g}$ grass $/ \mathrm{kg}$ and $10 \mathrm{~g}$ enzyme preparation $/ \mathrm{kg}$.

* The sugar concerned was perfused first or second.

The differences between jejunum and caecum perfusions, in ${ }^{14} \mathrm{C}$ recovery in plasma (Table 9) and in recovery interrelationships (Table 10), cannot be accounted for by a fundamental difference in absorption rate since there was plenty of overlap between the two regions (ranges in total radioactivity absorbed were $28-294 \times 10^{3}$ and $18-199 \times 10^{3} \mathrm{dpm}$ in jejunum and caecum respectively). A possible explanation that was tested was that in caecal perfusions sugars might have been converted to volatile fatty acids (VFA) before being absorbed by caecal bacteria left adhering to villi, and that these absorbed VFA did not pass from the liver into the circulation. However, when VFA were extracted by steam distillation from the homogenized livers of all birds with the diet $20 \mathrm{G} / \mathrm{E}$ pretreatment (Table 1), there was no difference between the minimal radioactivity levels of distillates from jejunum- and 
Table 9. Mean ${ }^{14} \mathrm{C}$ radioactivity (disintegrations/min) absorbed during perfusion (total from both sugars, and from second sugar (sugar 2) only), and its recovery from plasma, liver and flushed perfused intestinal segment*

(Mean values with their standard errors)

\begin{tabular}{|c|c|c|c|c|c|c|c|}
\hline & \multirow[b]{2}{*}{$n$} & \multicolumn{2}{|c|}{ Jejunum } & \multirow[b]{2}{*}{$n$} & \multicolumn{2}{|c|}{ Caecum } & \multirow{2}{*}{$\begin{array}{c}\text { Statistical } \\
\text { significance of } \\
\text { difference }\end{array}$} \\
\hline & & Mean & SE & & Mean & SE & \\
\hline Total $\left(\times 10^{3}\right)$ & 48 & $140 \cdot 8$ & $8 \cdot 4$ & 48 & $91 \cdot 5$ & $5 \cdot 8$ & $P<0.001$ \\
\hline Sugar $2\left(\times 10^{3}\right)$ & 48 & $66 \cdot 2$ & $4 \cdot 8$ & 48 & $36 \cdot 1$ & $3 \cdot 2$ & $P<0.001$ \\
\hline Plasma (per $0.5 \mathrm{ml}$ ) & 48 & $110 \cdot 5$ & $4 \cdot 7$ & 48 & $13 \cdot 2$ & $0 \cdot 7$ & $P<0.00 !$ \\
\hline Liver (per g wet wt) & 43 & 4303 & 480 & 43 & 4759 & 444 & NS \\
\hline Segment (per g wet wt) & 24 & 1845 & 429 & 25 & 1067 & 79 & NS \\
\hline
\end{tabular}

NS, not significant $(P>0.05)$.

* For details of procedures, see Table 2 and pp. 78-80.

Table 10. Cross correlations (r) between ${ }^{14} \mathrm{C}$ radioactivity (disintegrations/min) absorbed (total from both sugars, and from second sugar (sugar 2) only) and that recovered from plasma, liver and flushed perfused intestinal segment

\begin{tabular}{|c|c|c|c|c|}
\hline & Sugar 2 & Plasma & Liver & Segment \\
\hline \multicolumn{5}{|l|}{ Jejunum } \\
\hline$n$ & 48 & 48 & 43 & 24 \\
\hline Total & $0.57 * * *$ & $0.39 * *$ & -0.25 & -0.32 \\
\hline Sugar 2 & - & $0 \cdot 39^{* *}$ & -0.07 & -0.15 \\
\hline Plasma & - & - & 0.02 & -0.34 \\
\hline Liver & - & - & - & 0.23 \\
\hline \multicolumn{5}{|l|}{ Caecum } \\
\hline$n$ & 48 & 48 & 43 & 25 \\
\hline Total & $0.72^{* * *}$ & -0.02 & $-0.36^{*}$ & -0.13 \\
\hline Sugar 2 & - & $0 \cdot 14$ & $-0.29^{*}$ & -0.13 \\
\hline Plasma & - & - & -0.03 & 0.28 \\
\hline Liver & - & - & - & $-0.38^{*}$ \\
\hline
\end{tabular}

${ }^{*} P<0.05,{ }^{* *} P<0.01,{ }^{* * *} P<0.001$, all other correlation coefficients not significant $(P>0.05)$.

caecum-perfused birds. In fact, such an explanation seems unlikely anyway. This is because VFA appear to be absorbed entirely by passive diffusion (Sudo \& Duke, 1980), and so their absorption should be fastest when their concentrations in plasma are lowest. Their concentrations in portal blood reflect those in caecal contents (Cheng et al. 1987), which in turn declined with the increasing dietary grass levels used in the present study (Savory \& Knox, 1991); yet absorption rates in caecum declined with increasing grass (Tables 6 and 7 , first perfusion), when presumably VFA absorption rates should have increased. It appears, therefore, that sugars absorbed in caecum are treated differently, presumably in the liver, to those absorbed in jejunum.

\section{DISCUSSION}

Just as rates of intestinal sugar absorption in the fowl were found to be affected by dietary carbohydrate treatments in growing chicks (Gauthier et al. 1979), so the results of the present experiment indicate that they are also influenced by different levels of dietary fibre. The effects of dietary treatment observed here agree with those in the previous experiment 
of Savory \& Mitchell (1991; see p. 77) in one respect, in that there was a decline in hexose absorption rate in the caecum between diets $0 \mathrm{G}$ and 20G (Tables 6 and 7). There was no evidence here, however, of the increase in the hexose absorption rate in the jejunum seen previously between the same two diets. Nor were effects of dietary treatment here defined well enough to give any clear indication of their causation. Since villus lengths in jejunum and caecum did not differ between dietary treatments (Table 4), it seems unlikely that there would have been variation in absorptive surface area per unit length or weight of intestine. Systematic variation in a passive component of absorption, dependent on a downhill concentration gradient, also seems unlikely, especially with glucose which is normally regulated within narrow limits in the blood of fowls (Savory, 1987).

Rates of sugar absorption were closely correlated with rates of fluid loss from perfusate (Tables 6,7 and 8), perhaps due to combined effects of osmotic influences and solvent drag (Crane, 1974; Pappenheimer \& Reiss, 1987), as discussed by Savory \& Mitchell (1991). It is conceivable, therefore, that dietary effects on nutrient uptake could be at least partly indirect if the treatments themselves affect patterns of fluid transfer. However, no further information on fluid balance was obtained in the present study. The tendency for rates of sugar absorption and fluid loss in the caecum to decline after the first perfusion (Tables 6, 7 and 8), as also found in the previous experiments (Savory \& Mitchell, 1991), may possibly reflect suppression of an aldosterone-controlled fluid transfer mechanism in this (paired) organ, which is one of the main sites of water resorption in birds (Thomas \& Skadhauge, 1988).

It is also conceivable that dietary effects on sugar absorption could be due to variation in levels of constituents other than fibre, or to variation in food intake. The dietary treatments here, however, differed much more in fibre content than in either their crude protein or metabolizable energy contents (Table 1), and diet $20 \mathrm{C}$ treatment was the only one where food intake increased significantly (Table 3). Also, grass is sufficient in most vitamins and minerals (Bolton \& Blair, 1974), so it seems unlikely that a deficiency in one of these could have caused the observed effects of increasing grass. Nevertheless, food intake might be important, because it, rather than fibre per se, was concluded to be the main reason for gross changes in GI morphology in Japanese quail (Savory \& Gentle, 1976a).

Although their influence on absorption was not well defined, the present dietary treatments had more pronounced effects on gross dimensions of the duodenum, ileum, (total small intestine), caeca and colo-rectum (Table 4) and, hence, (presumably) on total surface area of mucosa and (potentially) total rates of absorption. Neither of the segments where rates of absorption were measured (jejunum and caecum), however, varied in a systematic way.

The $13 \%$ increase in daily food intake in response to dilution of a basal diet $(0 \mathrm{G})$ with $200 \mathrm{~g}$ powdered cellulose $/ \mathrm{kg}$ (diet 20C, Table 3 ) is like the $11 \%$ increase found in Japanese quail with the same treatment (Savory \& Gentle, 1976a), both reflecting compensation for inclusion of a practically inert filler. Effects of $200 \mathrm{~g}$ cellulose $/ \mathrm{kg}$ on GI dimensions were not the same in the two species, however, because although their caecal and colo-rectum responses were similar, gizzard weight increased in Japanese quail but not fowl, while small intestine length increased in fowl but not Japanese quail (Table 4; Savory \& Gentle, 1976a). Increasing the dilution level from 200 to $400 \mathrm{~g} / \mathrm{kg}$ caused increases in lengths of caeca but not small intestine with both grass and cellulose inclusions, in fowl and Japanese quail respectively (Table 4; Savory \& Gentle, 1976a).

Compared with the unsupplemented diet $20 \mathrm{G}$, addition of the polysaccharidase enzyme preparation (diet $20 \mathrm{G} / \mathrm{E}$ ) caused an $8 \%$ reduction in small intestine length and a $7 \%$ increase in caeca length (Table 4), possibly reflecting the $7 \%$ improvement in digestibility (Table 3 ) and increased availability of degraded dietary constituents for absorption or 
fermentation in those regions. Similar decreases in small intestine length have also been found in broiler chicks in which digestibility was improved and incidence of sticky droppings reduced by addition of pentosanase and $\beta$-glucanase enzymes to certain cerealbased diets (Hesselman \& Aman, 1986; Pettersson \& Aman, 1989). However, it seems unlikely that such an effect could have occurred here with the diet $20 \mathrm{G} / \mathrm{E}$ treatment, because, although the enzyme preparation used did contain the appropriate activities, there was no evidence with any of the diets (Table 1) of viscosity of digesta that might have been associated with their cereal component.

The increase in caeca length with diet $20 \mathrm{G} / \mathrm{E}$ was similar to that caused by diet $40 \mathrm{G}$, indicating increased availability of substrate for caecal fermentation with both treatments. In another experiment with broiler chicks, their caeca showed more evidence of fermentation and were heavier and longer when they were fed on a diet supplemented with $50 \mathrm{~g} / \mathrm{kg}$ of either arabinose or galacturonic or glucuronic acids, than they were with addition of glucose, galactose or xylose (Longstaff et al. 1988). Here, high concentrations of arabinose (a major constituent of hemicellulose) or fermentable oligosaccharides produced by action of the added enzyme could have been the reason for the larger caeca with diets $40 \mathrm{G}$ and $20 \mathrm{G} / \mathrm{E}$. The mechanism of trophic effects of diet on GI morphology is not known but may, perhaps, involve GI hormones (Lankisch, 1980).

Although absolute recoveries of ${ }^{14} \mathrm{C}$ radioactivity in the liver did not differ significantly between jejunum and caecum perfusions, it can be seen from Table 9 that a considerably greater proportion of the total activity absorbed was recovered in the liver after perfusions in the caecum. Activity was recovered in plasma after jejunum but not caecum perfusions, and total recovery in the whole perfused jejunum segment would have been considerably greater than in the caecum segment because the former was about 2.5 times heavier than the latter (see p. 81). If the apparent differences in the fate of sugars from jejunum and caecum cannot be accounted for by either a difference in the rate at which they were absorbed (and, hence, some threshold effect in the liver) or their conversion to VFA by caecal bacteria (see p. 85), then the implication seems to be that the liver can somehow distinguish and treat differently compounds absorbed in the two regions. It is difficult to envisage how this could be so, since venous blood from both jejunum and caecum enters the liver via the common hepatic portal vein (Nickel et al. 1977). Nevertheless, such a conclusion might make sense if most compounds absorbed in caeca, such as VFA and perhaps toxic substances as well, require different treatment anyway in the liver from those absorbed in the small intestine.

This research was funded jointly by a consortium of seven companies and the UK Department of Trade and Industry (Enzymes in Animal Feeds). Thanks are due to them, to Mrs A. Watson for her skilled technical assistance with the work, to Mr J. Culbert for doing the VFA extractions, and to Mrs C. McCorquodale for help with the statistical analysis.

\section{REFERENCES}

Bolton, W. \& Blair, R. (1974). Poultry Nutrition. London: H.M. Stationery Office.

Cheng, B.-Q., Trimble, R. P., Illman, R. J., Stone, B. A. \& Topping, D. L. (1987). Comparative effects of dietary wheat bran and its morphological components (aleurone and pericarp-seed coat) on volatile fatty acid concentrations in the rat. British Journal of Nutrition 57, 69-76.

Crane, R. K. (1974). Intestinal absorption of glucose. In Biomembranes, vol. 4A, Intestinal Absorption, pp. 541-553 [D. H. Smyth, editor]. London: Plenum Press.

Gauthier, A., Larbier, M. \& Blum, J. C. (1979). Influence des glucides alimentaires sur la croissance et la vitesse d'absorption intestinale du glucose et du fructose chez le poulet. (Influence of dietary sugars on the growth and rate of intestinal absorption of glucose and fructose in the chicken). Annales de Biologie Animale, Biochimie et Biophysique 19, 703-707. 
Gentle, M. J. \& Savory, C. J. (1975). The effect of dietary dilution on the intestinal anatomy of the Japanese quail (Coturnix coturnix japonica). Research in Veterinary Science 19, 284-287.

Hesselman, K. \& Aman, P. (1986). The effect of $\beta$-glucanase on the utilization of starch and nitrogen by broiler chickens fed on barley of low or high viscosity. Animal Feed Science and Technology 15, 83-93.

Krebs, H. A. \& Henseleit, K. (1932). Untersuchungen über die Harnstoffbildung im Tierkörper. (Research into the urea formation of the animal body). Hoppe-Seyler's Zeitschrift für Physiologische Chemie 210, 33-66.

Lankisch, P. G. (1980). Trophic effects of gastrointestinal hormones. Clinics in Gastroenterology 9, 773-784.

Leopold, A. S. (1953). Intestinal morphology of gallinaceous birds in relation to food habits. Journal of Wildlife Management 17, 197-203.

Levin, R. J. \& Mitchell, M. A. (1982). Intestinal adaptations to fasting - use of corrected kinetic parameters to assess responses of jejunal and ileal absorption in vivo. In Mechanisms of Intestinal Adaptation, pp. 103-110 [J. W. L. Robinson, R. H. Dowling and E. O. Riecken, editors]. Lancaster : MTP Press Ltd.

Levin, R. J., Mitchell, M. A. \& Barber, D. C. (1983). Comparison of jejunal and ileal absorptive functions for glucose and valine in vivo - a technique for estimating real $K_{m}$ and $J_{\max }$ in the domestic fowl. Comparative Biochemistry and Physiology 74A, 961-966.

Lewin, V. (1963). Reproduction and development of young in a population of California quail. Condor 65 , $249-278$.

Lis, M. T., Crampton, R. F. \& Matthews, D. M. (1972). Effect of dietary changes on intestinal absorption of L-methionine and L-methionyl-L-methionine in the rat. British Journal of Nutrition 27, 159 - 167.

Longstaff, M. A., Knox, A.\& McNab, J. M. (1988). Digestibility of pentose sugars and uronic acids and their effect on chick weight gain and caecal size. British Poultry Science 29, 379-393.

Moss, R. (1972). Effects of captivity on gut lengths in red grouse. Journal of Wildlife Management 36, 99-104.

Moss, R. (1974). Winter diets, gut lengths, and interspecific competition in Alaskan ptarmigan. Auk 91, $737-746$.

Nickel, R., Schummer, A. \& Seiferle, E. (1977). Anatomy of the Domestic Birds (translated by W. G. Siller and P. A. L. Wight). Berlin, Hamburg: Verlag Paul Parey.

Pappenheimer, J. R. \& Reiss, K. Z. (1987). Contribution of solvent drag through intercellular junctions to absorption of nutrients by the small intestine of the rat. Journal of Membrane Biology 100, 123 136.

Peddie, J., Dewar, W. A., Gilbert, A. B. \& Waddington, D. (1982). The use of titanium dioxide for determining apparent digestibility in mature domestic fowls (Gallus domesticus). Journal of Agricultural Science 99, 233-236.

Pendergast, B. A. \& Boag, D. A. (1973). Seasonal changes in the internal anatomy of spruce grouse in Alberta. Auk 90, 307-317.

Pettersson, D. \& Aman, P. (1989). Enzyme supplementation of a poultry diet containing rye and wheat. British Journal of Nutrition 62, 139-149.

Savory, C. J. (1987). How closely do circulating blood glucose levels reflect feeding state in fowls? Comparative Biochemistry and Physiology 88A, 101-106.

Savory, C. J. \& Gentle, M. J. (1976a). Effects of dietary dilution with fibre on the food intake and gut dimensions of Japanese quail. British Poultry Science 17, 561-570.

Savory, C. J. \& Gentle, M. J. (1976 b). Changes in food intake and gut size in Japanese quail in response to manipulation of dietary fibre content. British Poultry Science 17, 571-580.

Savory, C. J. \& Knox, A. I. (1991). Chemical composition of caecal contents in the fowl in relation to dietary fibre level and time of day. Comparative Biochemistry and Physiology 100A, 739-743.

Savory, C. J. \& Mitchell, M. A. (1991). Absorption of hexose and pentose sugars in vivo in perfused intestinal segments in the fowl. Comparative Biochemistry and Physiology 100A, 969-974.

Seal, C. J. \& Mathers, J. C. (1989). Intestinal zinc transfer by everted gut sacs from rats given diets containing different amounts and types of dietary fibre. British Journal of Nutrition 62, 151-163.

Sudo, S. Z. \& Duke, G. E. (1980). Kinetics of absorption of volatile fatty acids from the ceca of domestic turkeys. Comparative Biochemistry and Physiology 67A, 231-237.

Thomas, D. H. \& Skadhauge, E. (1988). Transport function and control in bird caeca. Comparative Biochemistry and Physiology 90A, 591-596. 